\title{
A non-equilibrium sediment transport model for rill erosion
}

\author{
Q. Q. Liu, ${ }^{1}$ L. Chen, ${ }^{2}$ J. C. $\mathrm{Li}^{1}$ and V. P. Singh ${ }^{3 *}$ \\ ${ }^{1}$ Institute of Mechanics, Chinese Academy of Sciences, Beijing 100080, People's Republic of China \\ ${ }^{2}$ Desert Research Institute, Las Vegas, NV 89119, USA \\ ${ }^{3}$ Department of Biological and Agricultural Engineering, Texas A and M University, Scoates Hall, 2117 TAMU, College Station, Texas 77843-2117, \\ Texas, USA
}

\begin{abstract}
:
Sediment transport in rill flows exhibits the characteristics of non-equilibrium transport, and the sediment transport rate of rill flow gradually recovers along the flow direction by erosion. By employing the concept of partial equilibrium sediment transport from open channel hydraulics, a dynamic model of rill erosion on hillslopes was developed. In the model, a parameter, called the restoration coefficient of sediment transport capacity, was used to express the recovery process of sediment transport rate, which was analysed by dimensional analysis and determined from laboratory experimental data. The values of soil loss simulated by the model were in agreement with observed values. The model results showed that the length and gradient of the hillslope and rainfall intensity had different influences on rill erosion. Copyright $\subset 2006$ John Wiley \& Sons, Ltd.
\end{abstract}

KEY WORDS dynamic model; rills; rill erosion rate; non-equilibrium sediment transport; sediment transport capacity

Received 16 March 2005; Accepted 17 January 2006

\section{INTRODUCTION}

Soil erosion on hillslopes is generally comprised of erosion due to raindrop splash, interrill erosion by sheet flow, and rill erosion by concentrated flow in rills. Rill erosion is commonly observed worldwide when rainstorms occur on steep slopes, as in the Loess Plateau area of China.

The characteristics of rill flow and erosion are different from those of sheet flow and erosion, and the rill erosion is a major contributor to erosion from hillslopes. Investigations (Govers and Poesen, 1988; Poesen et al., 1998) showed that rill erosion leads to a significant increase in the rate of erosion from hillslopes. In the Loess Plateau area of China, the soil loss from rill erosion, commonly, takes up about $70-96 \%$ of the total soil loss on slopes (Zheng and Kang, 1998). In addition, when rill erosion occurs on slopes, most of the sediment eroded by sheet flow only travels a short distance, then converges into micro-scale channels called rills and is mainly transported by rill flow. This suggests that rill erosion is of principal importance for prediction of soil erosion, when rills are prevalent on hillslopes.

Owing to the heterogeneity of soil (soil types, bulk density, moisture content, porosity, diameter of soil particles, etc.), irregularity of hillslope surface, and instability of flow, the initiation and development of rills partly exhibit randomness. The length, width, and depth of rills change as erosion progresses. The generally accepted viewpoint for the formation of rills, following Horton

\footnotetext{
* Correspondence to: V. P. Singh, Department of Biological and Agricultural Engineering, Texas A and M University, Scoates Hall, 2117 TAMU, College Station, Texas 77843-2117, Texas, USA.
}

E-mail: vsingh@tamu.edu
(1945), is that they are the result of accidental concentrations of flow. Also, rills are often obliterated by agricultural practices in cultivated areas. Foster et al. (1984a,b), Rauws and Govers (1988), Crouch and Novruzi (1989), Merz and Bryan (1993), Lei and Tang (1998), and Zhang (1999) investigated rill erosion characteristics, such as the critical condition for rill generation and hydraulic properties of rill flow. The initiation of rills was thought to depend on the hydraulic characteristics of overland flow. The rills tend to occur in regular patterns and their geometric parameters exhibit a good relationship with hydraulic properties, such as discharge of rill flow. Using the unit discharge, flow momentum, or flow energy of rill flow, some critical condition of rill formation was decided, and some empirical formulas of rill erosion were established, based on experimental data. Shainberg et al. (1996) carried out a laboratory investigation into the interactive effects of flow characteristics and soil properties on rill erosion. Sirjacobs et al. (2001) studied the effect of flow interruption on rill erosion for different soils. They found that interruption flow obviously reduced rill erosion and the reduced effect depended on soil properties and rill flow rate. The multitudinous factors, such as the properties of soil, surface condition of slopes, and flow dynamics characteristics, complicate the modelling of rill erosion. Therefore, many empirical models, based on field observations or laboratory experiments, have been proposed for estimating the rill erosion rate (Gilley et al., 1990; Zhang et al., 1998). Typically, rill erosion has been modelled using the universal soil loss equation (Wischmeier and Smith, 1978; Renard et al., 1997), which is a model of surface wash and rill erosion based upon rainfall erosivity, terrain, soil erodibility and vegetation cover. However, most empirical relationships 
do not incorporate physical mechanisms and cover only a limited parameter range and are region specific.

Accordingly, there seems to be a shift in emphasis from the empirical approach to the process-based dynamic approach to rill erosion. Significant attention has been paid in recent years to a comprehensive understanding and description of the processes of rill erosion and sediment transport. Studies related to the mechanics of rill erosion have shown that the rates of soil detachment are inversely dependent upon the magnitude of the sediment load at a given time and location on the soil surface (Rice and Wilson, 1990; Cochrane and Flanagan, 1996; Merten et al., 2001). The basis for this effect was investigated by Foster and Meyer (1972a). Hairsine and Rose (1992) utilized the concept of flow energy in their rill erosion. The models of this kind produce results that are somewhat similar in terms of soil detachment and sediment load as a function of downslope distance in a rill. Sediment load will approach an equilibrium concentration representing a transport limiting state due to energy limitation or the formation of sediment cover over the soil bed. Elliot and Laflen (1993) developed a rill erosion model that includes the down-cut erosion of rill flow, the rill head erosion (of tracing to the source), and the slide of rill walls. This model can simulate the process of rill development, but the process of sediment transport was not considered in detail. Favis-Mortlock (1998) constructed a model, called RillGrow, which applied simple rules to the movement of individual runoff 'packets' on a grid of microtopographic heights. Packet routing in the model was controlled only by microtopography. As each packet moved across the grid, it eroded the surface, using a stream-powerbased expression developed by Nearing et al. (1997). This model can describe the spatial variability of the rill system development and deal with the feedback of microtopography. Since no explicit separation is made between rill and interrill processes, some important process descriptions (e.g. sediment transport in rill flow) are ignored.

The rill erosion model embedded in the WEPP model has been applied in practice in recent years (Huang et al., 1996). In this model, sediment transport is treated using sediment mass conservation and the rate of rill erosion is considered to depend on the difference between the maximum sediment transport capacity and the actual sediment transport rate of rill flow (Foster et al., 1989). Lei et al. (1998) developed a finite-element model for rill erosion that took into account the morphological development of rills during the erosion process, especially the circular feedback loop between flow hydraulics (which drives the erosion process) and erosion (which causes morphological changes in the rill slope and width) and the impact of the changing bed morphology on the hydraulics of flow. The results of this model indicated that the erosion process in rills can be far more complex than described by the earlier models. These models have implied the characteristics of the non-equilibrium nature of sediment transport in rill flows, but do not clearly give the concept and the formulation for the method of unsaturated sediment transport.

The non-equilibrium nature of sediment transport is an important characteristic of rill flow due to the limited length of rills on hillslopes, and the recovery of sediment transport rate in rill flows undergoes a gradual change (Li et al., 2003). The recovery of sediment transport is a complex process and depends on the properties of soil and flow dynamics. Most of the previous investigations did not adequately consider this characteristic of rill erosion. Furthermore, there is a void in the basic relationship and mathematical expression for the recovery process of sediment transport in rill flows. Therefore, the objectives of this study were twofold. The first objective was to investigate the characteristics of non-equilibrium sediment transport of rill flow and develop a physically based, partial equilibrium transport model for rill erosion. The second objective was to establish a relationship between the recovery of sediment transport rate and the soil and flow properties using theoretical analysis and experimental data of loess soil on the Loess Plateau area of China. This enabled us to decide the restoration coefficient of sediment transport capacity suggested in the model.

\section{RILL EROSION MODEL}

Rills have complicated shapes, and to treat a rill as a stream channel it is necessary to simplify the rill flow hydraulics. In WEPP, for example, rills are assumed to have a uniform spacing, a uniform rectangular crosssection, and a width that is a function only of flow rate; all rills are assumed to be equally hydrologically efficient (Gilley et al., 1989). Recognizing that the slope surface and soil properties are different from one region to another, it is hypothesized here that rills on a hillslope can be represented by prism-type grooves and that they are uniformly distributed. Clearly, this assumption will be crude for converging or diverging hillslope landscapes.

\section{Dynamic model}

Rill flow is different from sheet runoff in hydraulic properties that depend on the relative magnitude of inertia and viscous forces. Like flows in rivers and streams, inertia forces largely overcome viscous forces in rill flows. The Reynolds number of rill flow is large and the flow is turbulent. Another major difference between rill flow and sheet flow is related to the flow depth. For a given particle size, the transport of sediment by saltation and suspension in overland flow is very limited due to the reduced flow depth. Therefore, rill flow and stream flow share some similarities, such as the hydraulic properties of flows, the detachment of soil particles and the transport of sediment.

Sediment transport in rill flows satisfies the sediment mass conservation, which can be expressed as

$$
\frac{\partial h C}{\partial t}+\frac{\partial q C}{\partial x}=G_{\text {up }}-G_{\text {down }}
$$


where $h(\mathrm{~m})$ is the flow depth, $C\left(\mathrm{~kg} \mathrm{~m}^{-3}\right)$ is the sediment concentration, $q\left(\mathrm{~m}^{2} \mathrm{~s}^{-1}\right)$ is the unit discharge of rill flow, $t$ and $x$ are the coordinates of time and space respectively, $G_{\text {up }}\left(\mathrm{kg} \mathrm{m}^{-2} \mathrm{~s}^{-1}\right)$ is the entrainment flux of sediment from bed, and $G_{\text {down }}\left(\mathrm{kg} \mathrm{m}^{-2} \mathrm{~s}^{-1}\right)$ is the settling flux of sediment.

Equation (1) is a convective equation with source and sink terms. If sediment transport in rills is assumed steady, Equation (1) simplifies to

$$
\frac{\mathrm{d} q_{\mathrm{s}}}{\mathrm{d} x}=G_{\mathrm{up}}-G_{\mathrm{down}}
$$

where $q_{\mathrm{s}}=q C\left(\mathrm{~kg} \mathrm{~m}^{-1} \mathrm{~s}^{-1}\right)$ is the sediment transport rate per unit width.

Assuming that the probability of settling of sediment particles during time $t_{0}$ is $\lambda$, the settling rate of sediment in water with depth of $h_{0}$, i.e. the settling flux of sediment, can be written as

$$
G_{\text {down }}=\lambda \frac{h_{0}}{t_{0}} C=\lambda \omega C
$$

Based on the mass conservation law, the entrainment flux of sediment from bed, as sediment transport reaches an equilibrium situation, is

$$
G_{\text {up }}=\lambda \omega C_{*}
$$

where $\omega\left(\mathrm{m} \mathrm{s}^{-1}\right)$ is the settling velocity of sediment particles and $C_{*}\left(\mathrm{~kg} \mathrm{~m}^{-3}\right)$ is the saturated sediment concentration of flow.

By substitution of Equations (3) and (4) into Equation (2), one obtains

$$
\frac{\mathrm{d} q_{\mathrm{s}}}{\mathrm{d} x}=\frac{\lambda \omega}{q}\left(q C_{*}-q C\right)=\alpha\left(T_{\mathrm{c}}-q_{\mathrm{s}}\right)
$$

where $T_{\mathrm{c}}\left(\mathrm{kg} \mathrm{m}^{-1} \mathrm{~s}^{-1}\right)$ represents the unit transport capacity of rill flow, $q_{\mathrm{s}}\left(\mathrm{kg} \mathrm{m}^{-1} \mathrm{~s}^{-1}\right)$ is the actual sediment transport rate per unit width, and $\alpha\left(\mathrm{m}^{-1}\right)=$ $\lambda \omega / q$ is a coefficient. The reciprocal $1 / \alpha$ has a length dimension and denotes the distance over which the sediment concentration of rill flow re-establishes from zero to the maximum capacity, i.e. maximum sediment transport. Thus, parameter $\alpha$ can be termed the restoration coefficient of sediment transport capacity. In general, a certain distance is required for the recovery of sediment concentration from clear water to the saturation state (Chien and Wan, 1999). The distance required for the recovery of sediment concentration is not, in general, the same for different flow and sediment conditions, i.e. the parameter $\alpha$ is not a constant; rather, it depends on flow properties and sediment condition. Therefore, the sediment transport in rill flow generally belongs to the process of non-equilibrium sediment transport due to the limited length of slopes (Li et al., 2003).

Actually, the term on the right-hand side of Equation (5) is just the rill erosion rate $D_{\mathrm{r}}$, i.e.

$$
D_{\mathrm{r}}=\alpha\left(T_{\mathrm{c}}-q_{\mathrm{s}}\right)
$$

Equation (6) shows that the rate of rill erosion is proportional to the difference between the maximum sediment transport capacity of rill flow and the actual sediment transport rate. It is also in agreement with the hypothesis used in the rill erosion model embedded in WEPP. Consequently, two aspects should be pointed out regarding Equation (6). The first is that the erosion capability of rill flow has a limiting value related to its transport capacity, which is no more than $\alpha T_{\mathrm{c}}$. The second is that the erosion capability of rill flow may decrease gradually as the sediment concentration increases. When the sediment concentration of rill flow reaches its maximum (or saturation), the rill erosion ceases.

If $T_{\mathrm{c}}$ is considered constant, then the soil is homogeneous and the sediment transport rate is zero at the point where a rill starts. Then, Equation (5) has an analytical solution:

$$
q_{\mathrm{s}}=T_{\mathrm{c}}\left(1-\mathrm{e}^{-\alpha x}\right)
$$

which can be considered as a basic formula describing rill erosion. From Equation (7), the restoration coefficient $\alpha$ can be expressed as

$$
\alpha=-\frac{\ln \left(1-q_{\mathrm{s}} / T_{\mathrm{c}}\right)}{x}
$$

Coefficient $\alpha$ is a complex parameter: it can be determined from experimental data of $q_{\mathrm{s}}$ and $T_{\mathrm{c}}$ for specified values of $x$. With $\alpha$ determined, the rill erosion rate can be estimated from Equation (5).

\section{Sediment transport formulae}

Since no formulae have been derived yet for sediment transport rate for rill flow, the sediment transport rate formulae developed for sediment transport in open channels are widely used. Especially, Four formulae in particular are often used to estimate sediment transport rate in rill flow: Yalin's formula (Yalin, 1963), Yang's formula (Yang, 1973), the Engelund and Fredsoe equation (Engelund and Fredsoe, 1976), and Low's formula (Low, 1989). Foster and Meyer (1972b) and Alonso et al. (1981), among others, recommended Yalins's formula (Yalin, 1963). Using experimental data obtained for soils of the Loess Plateau in China, Chen (2001) compared the performance of these four formulae in rill flow conditions and found that Yalin's formula was the best for rill erosion in the Loess Plateau area. This formula can be expressed as

$$
\begin{aligned}
T_{\mathrm{c}} & =G Y^{0.5}\left(Y-Y_{\mathrm{c}}\right) d[g d(s-1)]^{0.5} \rho_{\mathrm{s}} \\
G & =\frac{0.635}{Y_{\mathrm{c}}}\left[1-\frac{\ln \left(1+a s^{*}\right)}{a s^{*}}\right] \\
a & =\frac{2 \cdot 45}{s^{0.4}} Y_{\mathrm{c}}^{0.5} \quad s^{*}=\frac{Y-Y_{\mathrm{c}}}{Y_{\mathrm{c}}}
\end{aligned}
$$

where $Y=\tau /\left[\left(\rho_{\mathrm{s}}-\rho\right) g d\right]$ is the dimensionless shear stress, $Y_{\mathrm{c}}=\tau_{\mathrm{c}} /\left[\left(\rho_{\mathrm{s}}-\rho\right) g d\right]$ is the dimensionless critical shear stress, $\tau(\mathrm{Pa})$ is the flow shear stress, $\tau_{\mathrm{c}}(\mathrm{Pa})$ is the critical shear stress, $\rho_{\mathrm{s}}\left(\mathrm{kg} \mathrm{m}^{-3}\right)$ is the density of 
sediment, $\rho\left(\mathrm{kg} \mathrm{m}^{-3}\right)$ is the density of fluid, $s=\rho_{\mathrm{s}} / \rho, d$ ( $\mathrm{m}$ ) is the diameter of sediment ( $d$ can be replaced by $d_{50}$ for non-uniform sediment $), g\left(\mathrm{~m} \mathrm{~s}^{-2}\right)$ is the acceleration due to gravity.

In general, the process of scouring due to rill flow is similar to that in open channel flow. Dou's formula (Dou, 1999) was chosen to describe the critical shear stress $\tau_{\mathrm{c}}$. The formula expresses the law of incipient motion of sediments of various diameters, such as coarse sediment, fine sediment, cohesive sediment, and light sediment. For fine sediments like soil, this formula considers two components of the cohesive force between particles and the additional pressure of water film. In addition, slopes on the Loess Plateau are usually large, so the influence of slope on a soil particle's incipient motion should be taken into account. On a slope, this can be expressed as

$$
\begin{aligned}
\tau_{\mathrm{c}} & =k^{2} \rho\left(\frac{d^{\prime}}{d_{*}}\right)^{1 / 3}\left[3 \cdot 6 \frac{\rho_{\mathrm{s}}-\rho}{\rho} g \cos \theta d+\left(\frac{\gamma_{0}}{\gamma_{0 *}}\right)^{5 / 2}\right. \\
& \left.\times\left(\frac{\varepsilon_{0}+g \cos \theta h \delta \sqrt{\delta / d}}{d}\right)\right]
\end{aligned}
$$

where $\rho\left(\mathrm{kg} \mathrm{m}^{-3}\right)$ is the density of the fluid, $\rho_{\mathrm{s}}\left(\mathrm{kg} \mathrm{m}^{-3}\right)$ is the density of the sediment, $k(=0.128)$ is a nondimensional parameter, $d^{\prime}(\mathrm{m})$ is the characteristic diameter, $d_{*}(\mathrm{~m})$ is the referenced diameter (taken as $10 \mathrm{~mm}$ ), $h(\mathrm{~m})$ is the flow depth, $\varepsilon_{0}\left(\mathrm{~m}^{3} \mathrm{~s}^{-2}\right)$ is the adhesion force parameter, and $\delta(\mathrm{m})$ is the thickness parameter of the water film. It was found that the characteristic diameter $d^{\prime}=0.55 \mathrm{~mm}$ for fine sediment $(d \leq 0.5 \mathrm{~mm})$, such as soil (Dou, 1999), the adhesion force parameter $\varepsilon_{0}=1.75 \mathrm{~cm}^{3} \mathrm{~s}^{-2}$ for ordinary sediment, and the thickness parameter of the water film $\delta=2 \cdot 31 \times 10^{-5} \mathrm{~cm}$. $\gamma_{0}\left(\mathrm{~N} \mathrm{~m}^{-3}\right)$ is the dry specific weight of soil and $\gamma_{0 *}$ $\left(\mathrm{N} \mathrm{m}^{-3}\right)$ is the stable dry specific weight of soil, and can be determined empirically as

$$
\gamma_{0 *}=0.68 \gamma_{\mathrm{s}}\left(d / d_{0}\right)^{m} \quad m=0.08+0.014\left(d / d_{25}\right)
$$

where $\gamma_{\mathrm{s}}$ is the specific weight of sediment, $d_{0}=1 \mathrm{~mm}$, and $d_{25}$ is the grain diameter, meaning that $25 \%$ of the total particles by weight are finer.

\section{PARAMETER ESTIMATION}

In the present erosion model, two parameters, the width or wetted perimeter of rill flow (for determining the depth of rill flow) and the restoration coefficient of the sediment transport capacity, need to be determined first. In order to ascertain these two parameters, a series of rill erosion experiments was carried out in a soil flume, as shown in Figure 1 (Chen et al., 2005). The soil was first packed to a $20 \mathrm{~cm}$ thickness in the flume and adjusted to reach an actual bulk density of $1.3 \mathrm{~g} \mathrm{~cm}^{-3}$. The experimental flume is only $40 \mathrm{~cm}$ long. It is necessary to indicate that the flume was not long enough to simulate the formation of rills on a slope. Therefore, a $10 \mathrm{~cm}$ long, $5 \mathrm{~cm}$ wide and $2 \mathrm{~cm}$ deep groove from the outlet was artificially

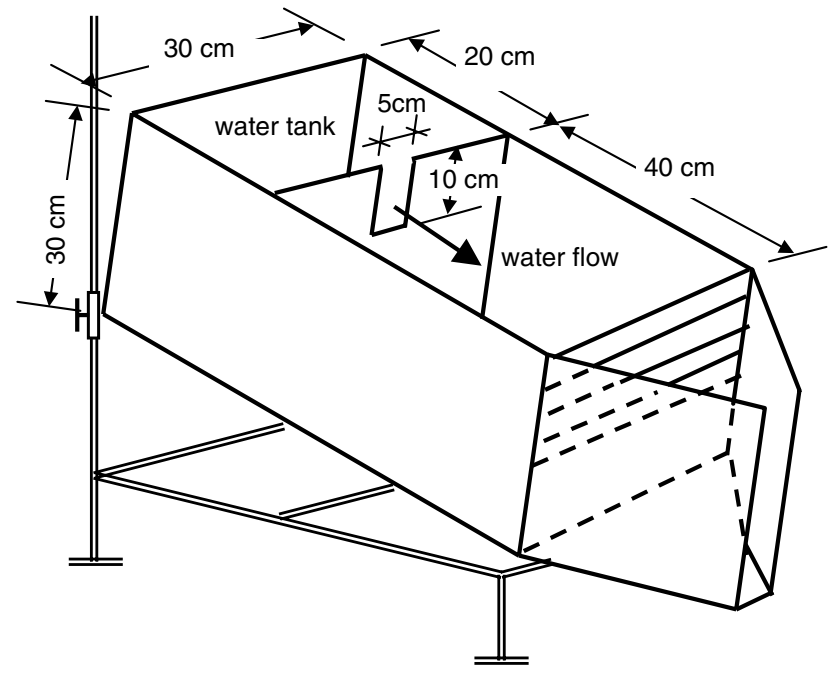

Figure 1. Sketch of experimental equipment. The slope can be adjusted according to experimental requirements

made along the middle line of the flume. This method assured that the flow in the groove directly formed rill erosion at the very beginning of the experiment and simulated the process of sediment transport in a reasonable manner. At the same time, instead of artificial rainfall, the water was steadily supplied at the top inlet of the flume, and directly flowed into the rill, which permitted an easy manipulation of the discharge of rill flow.

The soil used in the experiments was loess with a median diameter of $0.016 \mathrm{~mm}$. Five slopes $\left(5^{\circ}, 10^{\circ}, 15^{\circ}\right.$, $20^{\circ}$, and $\left.25^{\circ}\right)$ and five flow discharges $\left(0.01 \times 10^{-3}\right.$, $0.025 \times 10^{-3}, 0.05 \times 10^{-3}, 0.075 \times 10^{-3}$, and $0.1 \times$ $10^{-3} \mathrm{~m}^{3} \mathrm{~s}^{-1}$ ) for each slope were employed in the experiments. The rill erosion amount, the rill flow velocity, and the rill depth and width were measured (Chen et al., 2005). The cross-section shapes of most rills that formed in the flume were rectangular or echelon type. Figure 2 shows the formation of the rills after the experiment.

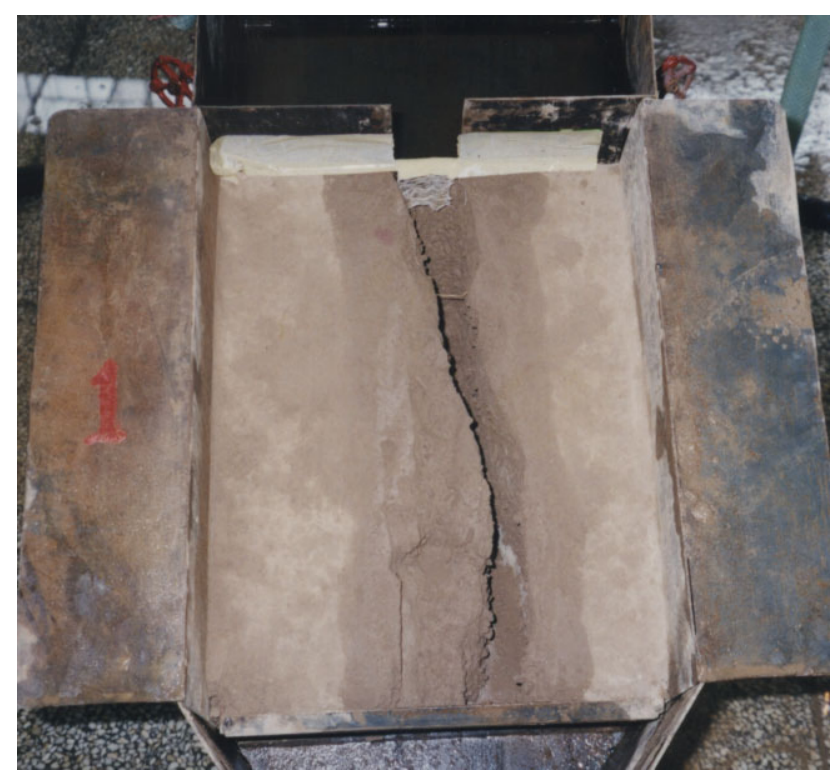

Figure 2. Rill modality after experimentation 


\section{Width and wetted perimeter of rill flow}

There is experimental and field evidence that the rill width is significantly correlated with runoff discharge and slope gradient. Figure 3 plots the experimental data of width and wetted perimeter of rill flow sections against the rill flow discharge on different slopes. Because the experimental flume was not enough long, and the development of the rill was fast during experiments, the observed experimental data exhibited great fluctuations. Nevertheless, the experimental results basically show that the width and wetted perimeter of rill flow sections increase as the discharge of the rill flow increases, and they decrease with increase in slope.

Using a multiple regression, the following formula was obtained:

$$
B=0 \cdot 596 Q^{0.316} S_{0}^{-0.23}
$$

where $B(\mathrm{~m})$ is the rill width, $Q\left(\mathrm{~m}^{3} \mathrm{~s}^{-1}\right)$ is the discharge of rill flow and $S_{0}=\sin \theta$ is the slope gradient (where $\theta$ is the hillslope angle). Equation (12) is similar to the relationship obtained by Zhang (1999) on Loess hillslopes. Comparison of the values of $B$ predicted by Equation (12) with those observed experimentally is shown in Figure 4a. The correlation coefficient $r=0.674$ and the root-mean square error RMSE $=1.611 \mathrm{~cm}$.

Experiments also showed that the wetted perimeter of rill flow was better related with runoff discharge and slope. By substituting the wetted perimeter $p(\mathrm{~m})$ for the rill width, the following formula was obtained:

$$
p=1 \cdot 5 Q^{0.37} S_{0}^{-0.245}
$$

Comparison of the values of $p$ predicted by Equation (13) with those observed experimentally is shown in Figure 4b. The correlation coefficient $r=0.901$ and $\mathrm{RMSE}=$ $1.299 \mathrm{~cm}$. Actually, the section shapes of most rills were irregular and echelon type rather than rectangular. Under the condition of discharge being constant, the wetted perimeter may reflect the hydraulic characteristics (such as hydraulic radius) and the interaction between flow dynamics and soil, compared with the width of rill flow.
This may be the reason why the wetted perimeter of rill flow was better related with runoff discharge and slope than the width of rill flow was.

\section{Restoration coefficient of sediment transport capacity}

In the present model, a parameter called the restoration coefficient of sediment transport capacity was used to express the recovery process of sediment transport capacity. In order to determine the parameter $\alpha$ from experimental data, let $L_{\alpha}$ (a length dimension) represent the distance that the sediment concentration of rill flow recovers from zero to a maximum value. Then, by definition:

$$
L_{\alpha}=1 / \alpha
$$

The value of $L_{\alpha}$ depends on the characteristics of rill flow and the soil. Considering the influence of various factors, such as the effective shear stress of rill flow $\left(\tau-\tau_{\mathrm{c}}\right)$, the hydraulic radius $R$, the velocity $u$, the diameter of soil particles $d$, the density of soil particles under water $\left(\rho_{\mathrm{c}}-\rho\right) g$, and the slope gradient $S_{0}$, through dimensional analysis, the following relation among dimensionless parameters was supposed and established:

$$
\frac{L_{\alpha}}{R}=f\left[\frac{\tau-\tau_{\mathrm{c}}}{\left(\rho_{\mathrm{s}}-\rho\right) g d}, \frac{u}{\sqrt{g d}}, S_{0}\right]
$$

Then, for the hypothesis of an exponential relation, a multiple regression of the experimental data yielded the following relation:

$$
\frac{L_{\alpha}}{R}=1.5 \times 10^{4}\left[\frac{\tau-\tau_{c}}{\left(\rho_{\mathrm{s}}-\rho\right) g d}\right]^{0.15}\left(\frac{u}{\sqrt{g d}}\right)^{-1} S_{0}{ }^{1.5}
$$

Comparison of the values of $L_{\alpha}$ predicted by Equation (16) with those observed experimentally is shown in Figure 5. The correlation coefficient $r=0.93$ and the RMSE $=0.352$.

With $\alpha$ or $L_{\alpha}$ estimated from Equation (16), the rill erosion rate can now be estimated from the proposed rill erosion model.

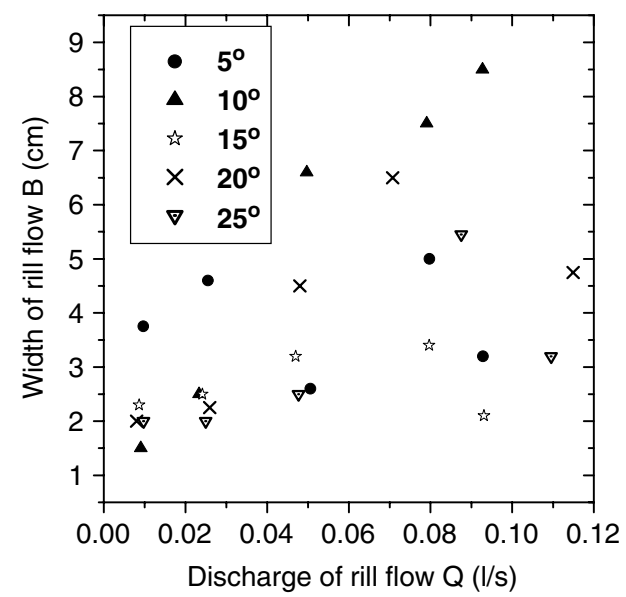

(a) Width of rill flow section

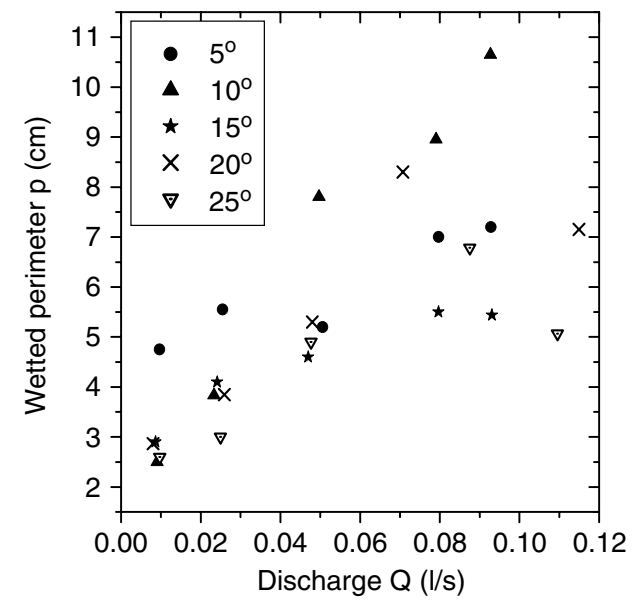

(b) Wetted perimeter of rill flow

Figure 3. Width and wetted perimeter of flow section vary with discharge for different slopes 


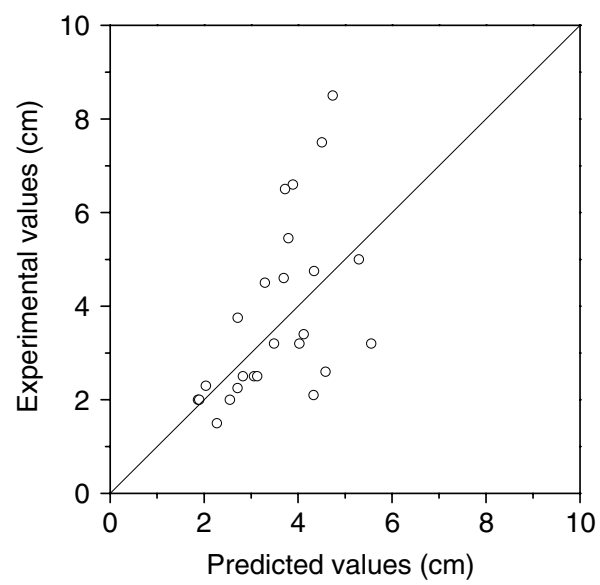

(a) Width of rill flow section, $B$

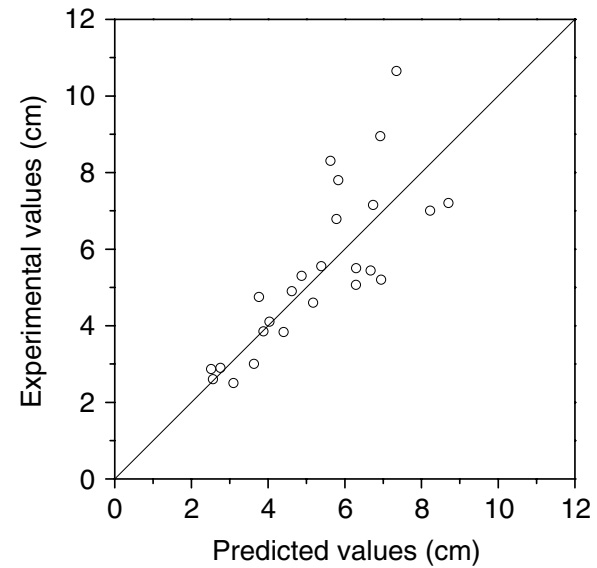

(b) Wetted perimeter of rill flow, $p$

Figure 4. Comparison of calculated and experimental results of $B$ and $p$

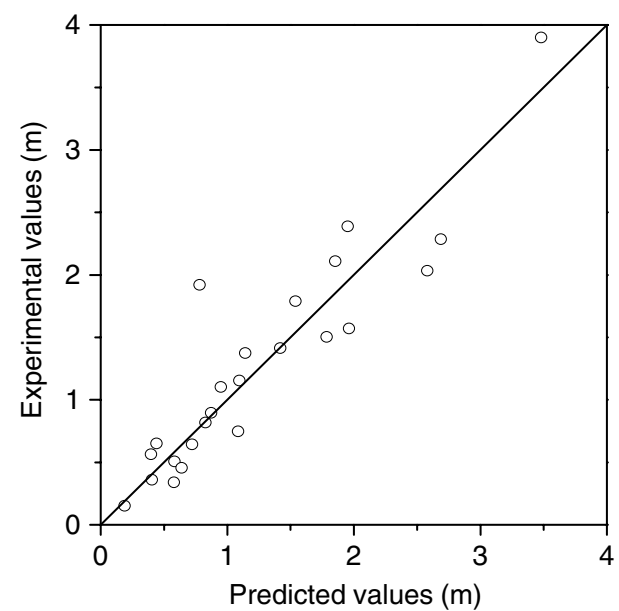

Figure 5. Comparison of calculated and experimental results of the $L_{\alpha}$ value $(r=0.93)$

\section{MODEL VALIDATION}

To test the rill erosion model developed above, two groups of rill erosion experiments were conducted in the Chinese State Key Laboratory of Soil Erosion and Dryland Farming in Loess Plateau. In the first group of experiments, seven sets of erosion tests were completed in a soil flume $200 \mathrm{~cm}$ long and $100 \mathrm{~cm}$ wide with a fixed slope of $25^{\circ}$. Instead of artificial rainfall, the water was supplied at the top inlet of the flume and five flow discharges from $0.05 \times 10^{-3}$ to $0.6 \times 10^{-3} \mathrm{~m}^{3} \mathrm{~s}^{-1}$ were used in the experiments. In the second group of experiments, a series of indoor artificial rainfall experiments were completed in a test plot $320 \mathrm{~cm}$ long and $100 \mathrm{~cm}$ wide. Rainfall was simulated by a dropformer type rainfall simulator, which produced drop-size distributions similar to natural rainfall, with raindrops forming at an average height of $16 \mathrm{~m}$. The rainfall intensity was adjustable in the range of $15-200 \mathrm{~mm} \mathrm{~h}^{-1}$. The soil used in the experiments was the local loess, as before. The soil was packed into the flume to a depth of $25 \mathrm{~cm}$ and controlled to reach a bulk density of $1.2-1.3 \mathrm{~g} \mathrm{~cm}^{-3}$. The total discharge and sediment transport rate were measured carefully at the outlet of the test flume.

In these experiments, three rills on average were distributed evenly on a $1 \mathrm{~m}$ wide hillslope. When a rill occurs on the slope, most runoff and sediment delivery from interrill areas concentrate into rill flow. The concept of conflux coefficient was used to describe the rate of discharge concentrating into rills and the discharge of overland flow in interrill areas. Here, the conflux coefficient of rill flow was empirically taken as $0 \cdot 8$, namely $80 \%$ of overland flow in interrill areas concentrated into rills. The wetted perimeter and the hydraulic radius of rill flow were obtained from Equation (13). The Manning roughness coefficient of rill flow was determined as $n=0.05$ for small discharges and $n=0.07$ for greater discharges according to the present experiments. The sediment transport due to rill erosion was calculated using the proposed rill erosion model of Equation (5) with the aid of the runoff discharge observed in the experiments. Figure 6 compares the model-simulated rill erosion rates with observed results in scouring experiments (the first group of experiments), and the agreement between them was satisfactory (RMSE $=22 \cdot 104 \mathrm{~g} \mathrm{~s}^{-1}$; ignoring an experimental value with obvious error, RMSE $=14.2 \mathrm{~g} \mathrm{~s}^{-1}$ ). Comparisons of simulated and observed rill erosion rates (the second group of experiments) are shown in Figure 7. In model simulation, the observed values of rill flow discharge were employed. However, the rill flow discharge was obtained by averaging the total discharge on the slope into three rills. The rill flow discharge was only an approximate observed result. According to these discrete values of rill flow discharges, the calculated values of rill erosion rate also displayed a little fluctuation. In addition, the observed values of erosion rate include the total of interrill erosion and rill erosion; however, the sheet erosion was not considered in the present model. Because interrill erosion is much smaller than erosion, its neglect in computation of erosion may bring a little error, but is unimportant. This is supported by the results of the proposed model, 


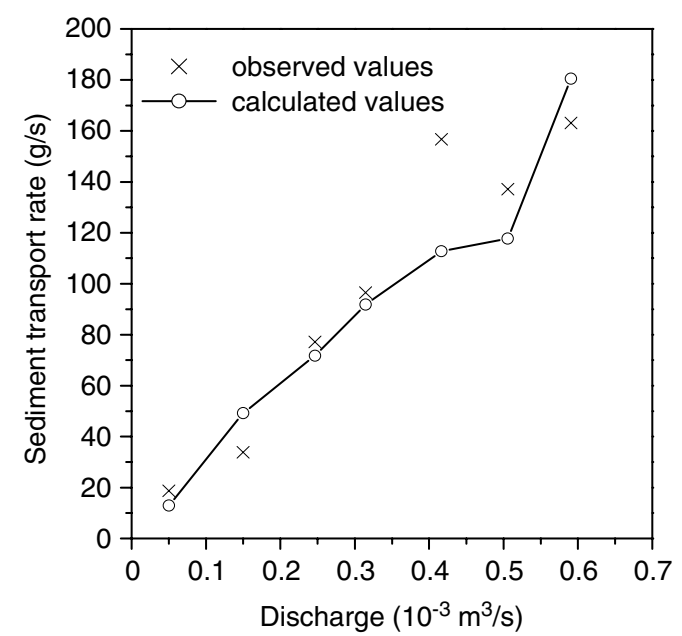

Figure 6. Comparison of simulated and observed rill erosion rates in scouring experiments

which simulates rill erosion on the Loess Plateau effectively.

\section{SENSITIVITY ANALYSIS}

In practice, it is difficult to determine the conflux coefficient of flow concentrating into rills from around the area and the rill length. In order to investigate the effect of the conflux coefficient and rill length on the predicted rill erosion, a sensitivity analysis of the model was performed. First, a set of parameters was taken as the reference values, as shown in Table I.

\section{Conflux coefficient}

In the above calculations, the conflux coefficient of rill flow was assumed to be a constant. When rill erosion has adequately developed to a certain stage, the assumption of constant conflux coefficient is acceptable based on the previous experiences. Actually, in most situations, a constant conflux coefficient is not in accordance with the practical reality. Because the formation and development
Table I. Standard parameters as reference values used in sensitivity analysis

\begin{tabular}{ll}
\hline $\begin{array}{l}\text { Saturated volumetric water content (effective } \\
\text { porosity) } \theta_{\mathrm{s}}(\%)\end{array}$ & 50 \\
$\begin{array}{l}\text { Initial volumetric water content } \theta_{\mathrm{i}}(\%) \\
\text { Soil saturated hydraulic conductivity }\end{array} \quad 15$ \\
$\quad$ (infiltration coefficient) $K\left(\mathrm{~mm} \mathrm{~min}^{-1}\right)$ & $0 \cdot 12$ \\
Soil suction $S(\mathrm{~m})$ & $0 \cdot 15$ \\
Sediment median grain size $d_{50}(\mathrm{~mm})$ & $0 \cdot 02$ \\
Soil dry specific weight $\gamma_{0}\left(\mathrm{~N} \mathrm{~m}^{-3}\right)$ & 1300 \\
Soil stable dry specific weight $\gamma_{0 *}\left(\mathrm{~N} \mathrm{~m}^{-3}\right)$ & 1100 \\
Slope gradient $S_{0}$ & $\sin \left(15^{\circ}\right)$ \\
Slope length $L(\mathrm{~m})$ & 20 \\
Slope width $W(\mathrm{~m})$ & 5 \\
Interrill spacing $D_{\mathrm{rr}}(\mathrm{m})$ & $0 \cdot 50$ \\
Conflux coefficient $c_{\mathrm{f}}$ & $0 \cdot 8$ \\
\end{tabular}

of rills generally originate from the downstream region of the hillslope, the rills commonly develop incompletely and the conflux coefficient on the upstream region of the hillslope is quite small. Here, two conflux coefficients were used to compare the calculated erosion rates: one used a constant value of 0.8 and the other was assumed to vary as

$$
c_{\mathrm{f}}=0 \cdot 8 \frac{x}{L}
$$

Using the proposed model and the runoff generation model of Chen et al. (2001), the runoff hydrograph and rill erosion rate were calculated. The sediment transport rate and the cumulative erosion amount calculated using constant and variable conflux coefficients are shown in Figure 8. The difference between the results of the two calculations is small, and the largest error is less than $4 \%$. This means that the proposed model was not sensitive to the sampled value of the conflux coefficient. If the conflux coefficients on the downstream portion of the hillslope were considered approximately equal, then the discharges of rill flow on the downstream portion were close, which yielded erosion rates close to that of rill flow. This shows that the total erosion depends mainly on the rill flow discharge located on the downstream zone

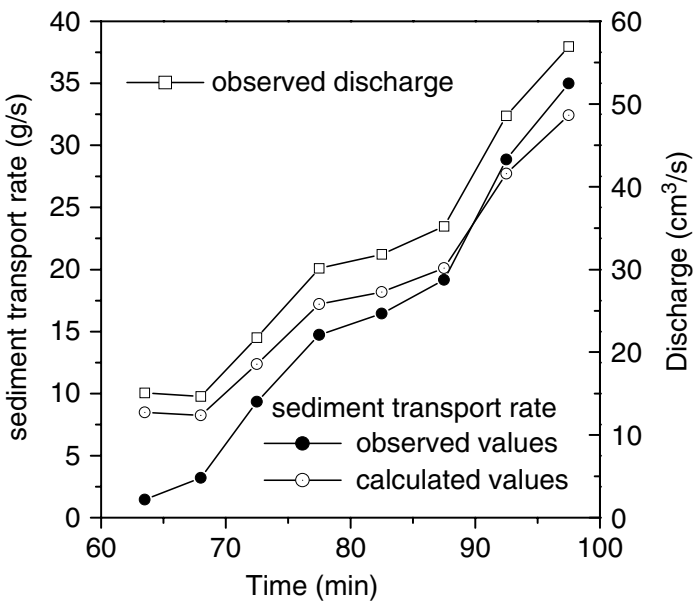

(a) Rain intensity: $1.0 \mathrm{~mm} / \mathrm{min}$, Slope gradient: $20^{\circ}$

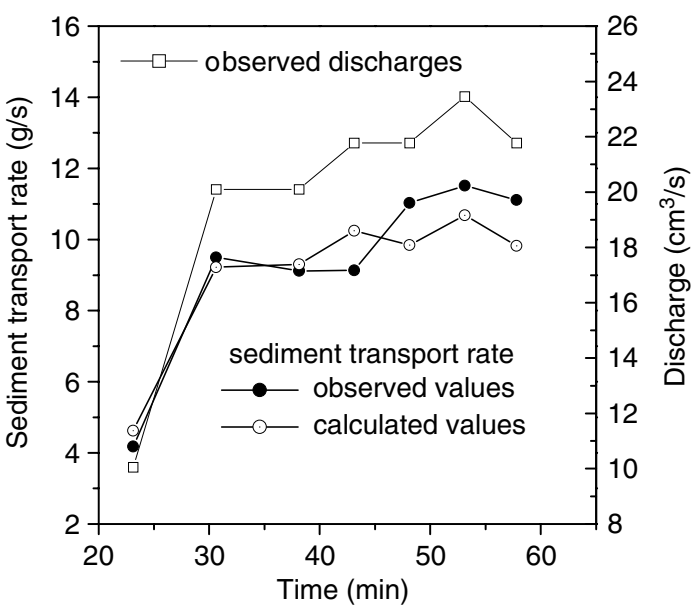

(b) Rain intensity: $1.71 \mathrm{~mm} / \mathrm{min}$, Slope gradient: $30^{\circ}$

Figure 7. Comparison of simulated and observed results in artificial rainfall experiments 


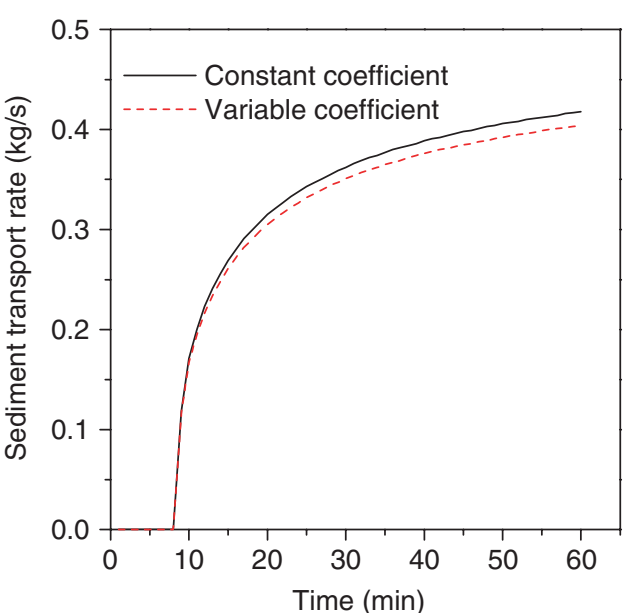

(a) sediment transport rate vs time

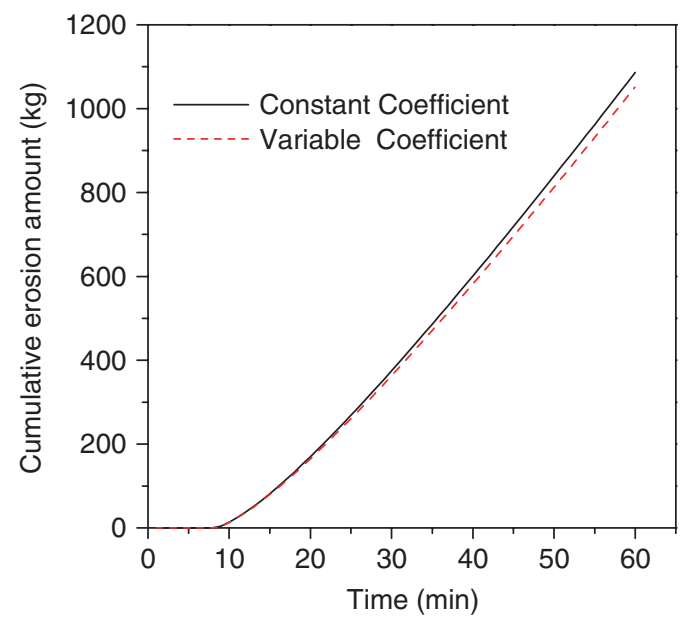

(b) Cumulative erosion amount vs time

Figure 8. Rill erosion for different conflux coefficients

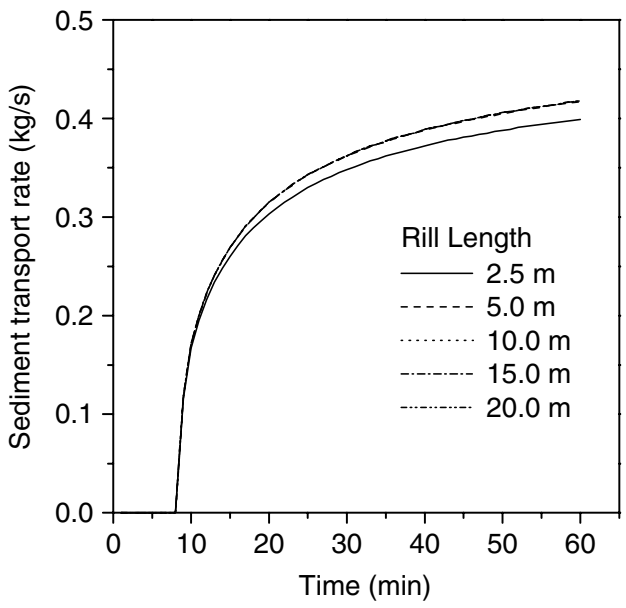

(a) sediment transport rate vs time

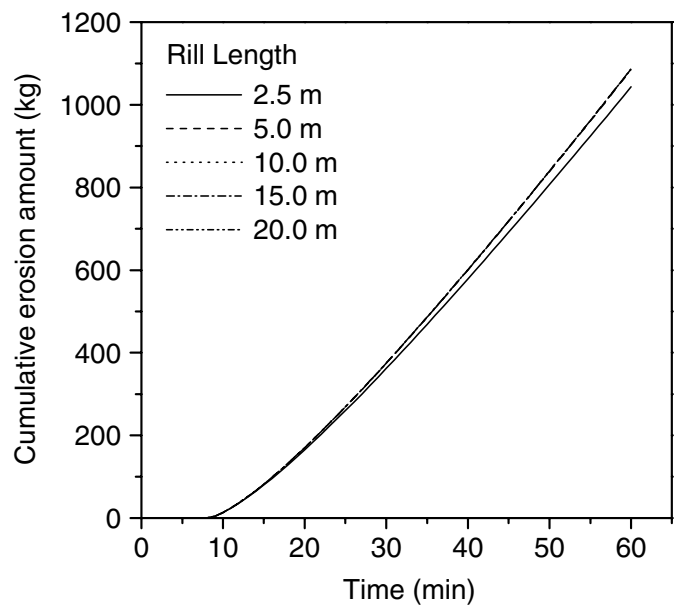

(b) Cumulative erosion amount vs time

Figure 9. Rill erosion for different rill lengths

of the hillslope where rill flow has a greater discharge. Owing to the undeveloped rills and small discharge of rill flows on the upstream region of the hillslope, the small conflux coefficients did not result in an obvious variation of rill erosion.

\section{Rill length}

In general, near the top of the hillslope, flow is low and there is hardly any rill erosion. Since the rill length is partly stochastic, it is desirable to evaluate the sensitivity of rill erosion to rill length. Taking five rill lengths, $2 \cdot 5,5,10,15$ and $20 \mathrm{~m}$, rill erosion was calculated as shown in Figure 9. The results of calculation show that the rate and the cumulative amount of erosion decrease as the rill length decreases, but the difference between them is less than $5 \%$. This indicates that the use of different rill lengths would not cause a significant error in the model results. When the rill length was short, there was no rill erosion on the upstream portion of the hillslope; therefore, the sediment concentration of flow on the downstream zone of the hillslope was low and the erosion rate of flow was high. If the sediment transport rate reaches the saturated transport capacity of rill flow, then the rill erosion rate depends only on the final discharge of rill flow for the same soil conditions. Because the same slope lengths generally lead to more or less the same rill flow discharge at the outlet, the sediment transport rate of rills with different lengths would tend to be equal through the interaction and the adjustment of flow and sediment concentration. The bed load transport in rill flow was not considered. This result reveals that different rill lengths would not cause a significant error in the model results.

\section{RILL EROSION CHARACTERISTICS}

Rill erosion for the reference parameter values shown in Table I was numerically simulated by using the present model with the aid of the model of overland flow generation (Chen et al., 2001) for varying rain intensity, slope gradient, and slope length. Figure 10 shows the simulated erosion amounts varying with time 


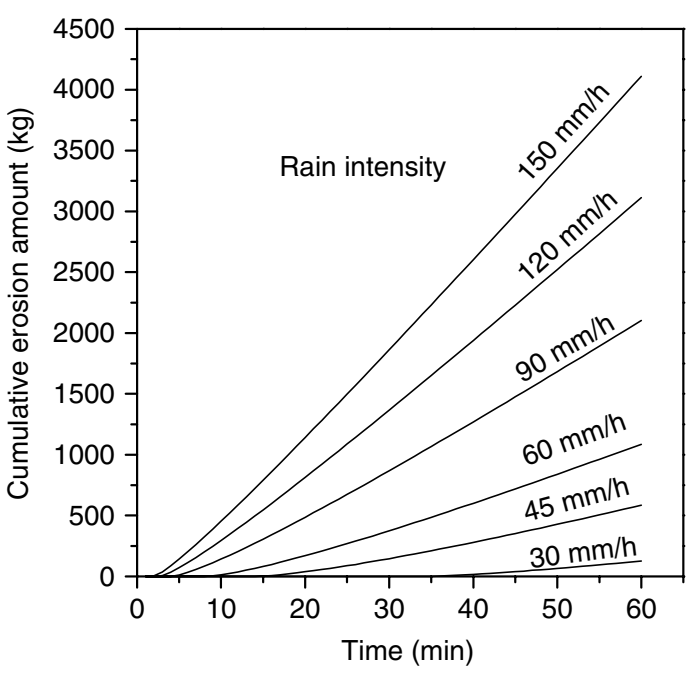

(a) For different rain intensities

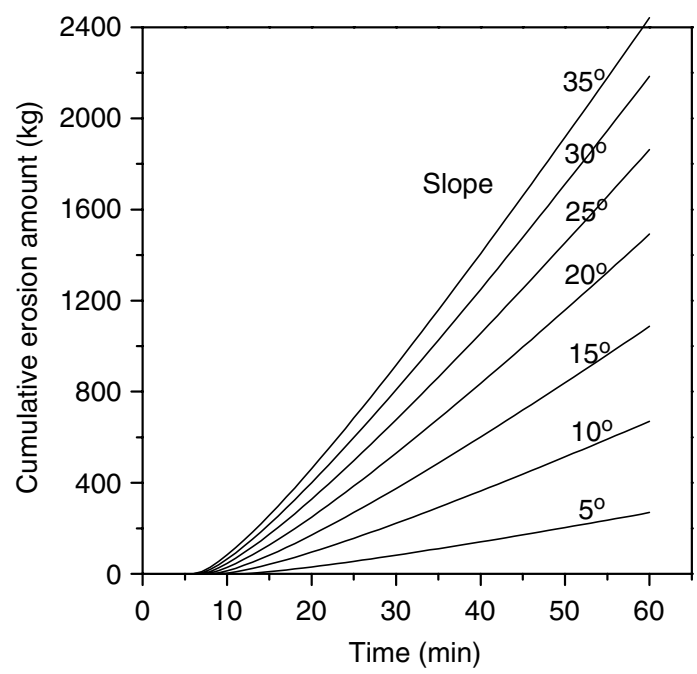

(b) for different slopes gradients

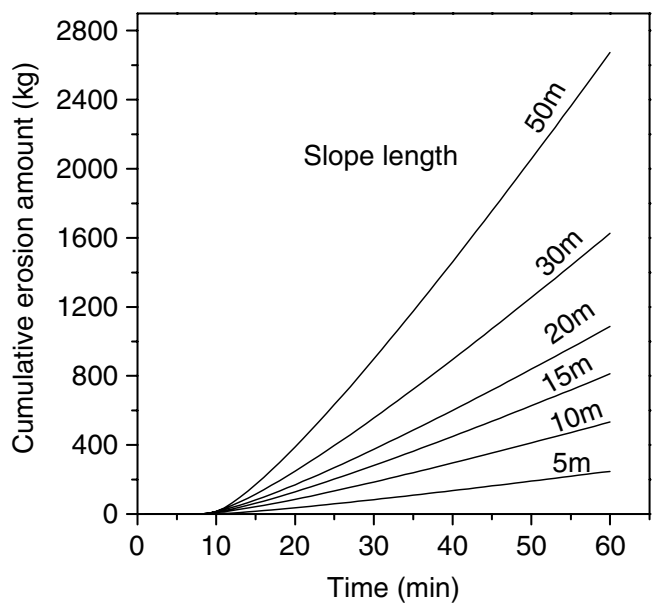

(c) For different slope lengths

Figure 10. Simulated results of rill erosion amount for different slope lengths, slope gradients and rain intensities

under different rain intensities, slope gradients and slope lengths.

Simulated results show that erosion amounts would be greatly different for different rainfall intensities, slope gradients, and slope lengths. The erosion amount obviously increased with rain intensity, accounting for larger runoff discharge during intensive rains. In addition, it was also found that the influence of rainfall intensity variation on the erosion rate was more obvious in slight rainfall than in heavy rainfall. The influence of slope gradient on rill erosion was similar to rain intensity. The erosion amount increased with the slope gradient. Although the slope gradient increase did not increase runoff discharge, it led directly to the increased shear stress of flow. As a result, the rill erosion rate may increase with an increase in the slope gradient.

Sensitivity analysis demonstrated that the use of different rill lengths for the same lengths of slope would not cause a significant error for erosion rate and amount. However, when slope lengths are different, erosion will be greatly different. Analysis of simulated results showed that both the sediment transport rate and the accumulated erosion amount increased remarkably as the slope length increased, which led to a greater increase of runoff discharge. In addition, the accumulated erosion amount increased non-linearly with the slope length. Generally speaking, the accumulated erosion amount increased rapidly at first and then increased linearly. This indicates that the main factor influencing rill erosion is runoff discharge under the same soil conditions, as different slope lengths reflect different runoff discharges at the outlet.

Furthermore, the variation of the soil erosion intensity along the hillslope length was calculated. As shown in Figure 11, the intensity of soil erosion first increased and attained a maximum value, and then it remained unchanged or decreased slightly with increasing slope length over a long period of time. Erosion occurring over a long time would form depressions in the middle part of the hillslope. This may be the reason that most hillslopes exhibit an inverse-S shape. Where this kind of slope shape is formed, it would continue to keep this shape because soil erosion is more intense in the portion having a greater slope and weaker in the portion having a smaller slope. 


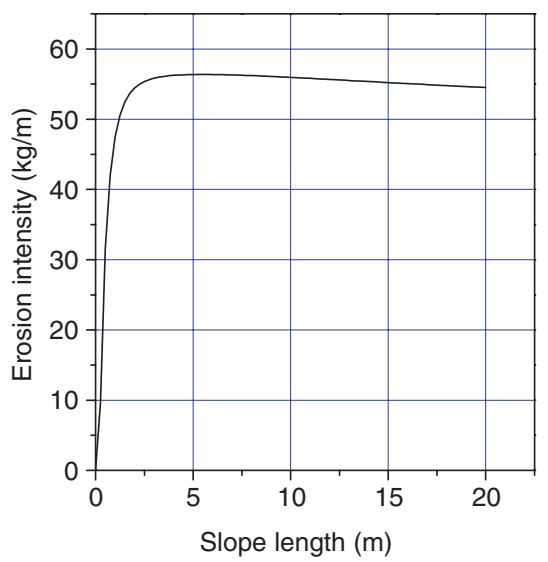

Figure 11. Variation of erosion intensity along slope length

\section{SUMMARY AND CONCLUSIONS}

1. Sediment transport in rill flow is a typical process of non-equilibrium transport. Commonly, the sediment transport rate is unsaturated and needs to recover within a distance, which decides the rill erosion rate along the streamwise direction. In order to describe the non-linear erosion process of rill along slope reasonably, a non-equilibrium sediment transport model of rill erosion on slopes was developed by employing the concepts of recovery of sediment transport capacity.

2. The section shape of rill flow is of primary significance for the simulation of rill erosion. Although the formation of rills exhibits some randomness, they tend to occur in regular patterns that have a good relation with rill flow discharge. Using experimental data, two empirical relationships were established that describe the width and wetted perimeter of rill flow varying with slopes and discharges of rill flow. Experimental observations show that the wetted perimeter of rills is strongly related to the rill discharge and slope.

3. For non-equilibrium sediment transport, the process of sediment transport rate depends on soil properties and flow hydraulic conditions. The restoration coefficient of sediment transport capacity $\alpha$, which is a measure of the recovery of sediment transport capacity, and its variation were determined from experimental data. Erosion experiments show that the proposed model may effectively simulate rill erosion on the Loess Plateau of China.

4. The formation and the development of rill erosion are complex, which means that in application it is not easy to determine the length of rills and conflux rate from interrills into rills. Sensitivity analysis of the model shows that different conflux coefficients and rill lengths do not have a major effect on rill erosion. This makes the rill erosion model quite practical.

5. The recovery process of sediment transport capacity of rill flow depends on the soil and flow properties. For a steady discharge of rill flow, the sediment transport rate of rill flow will gradually increase to a constant (sediment transport capacity) within a definite distance. For a sufficiently long rill, the erosion rate of rill will gradually decrease to zero and reach an equilibrium state of sediment transport. Sometimes, when the sediment transport rate of rill flow is greater than its sediment transport capacity (e.g. as the upper portion of the rill bed is eroded, resulting in a decrease in the bed slope), the sediment deposition of rills will occur in rills. These phenomena exhibit the characteristics of non-equilibrium sediment transport and the feedback of the restoration coefficient. Actually, the discharge of rill flow on hillslopes varies and increases along the slope because of the conflux of overland flow. The results of calculation in this study show that the rill erosion amount increases non-linearly with rain intensity, slope gradient, and slope length.

\section{ACKNOWLEDGEMENTS}

This research was financially supported by the National Natural Science Foundation of China (no. 10332050 and no. 19832060).

\section{REFERENCES}

Alonso CV, Neibling WH, Foster GR. 1981. Estimating sediment transport capacity in watershed modeling. Transactions of the ASAE 24: $1211-1226$.

Chen L. 2001. Dynamics of overland flow and rill erosion on slopes. Doctoral thesis, Institute of Mechanics, Chinese Academy of Sciences, Beijing, China.

Chen L, Liu QQ, Li JC. 2001. Runoff generation characteristics in typical erosion regions on the Loess Plateau. International Journal of Sediment Research 16(4): 473-485.

Chen L, Liu QQ, Li JC. 2005. Scouring experimental study on rill erosion on the slopes. Chinese Journal of Hydrodynamics, Series A 20(6): $761-766$

Chien N, Wan ZH. 1999. Mechanics of Sediment Transport, McNown JS (transl.). ASCE Press: 347-356.

Cochrane TA, Flanagan DC. 1996. Detachment in a simulated rill. Transactions of the ASAE 40: 111-119.

Crouch RJ, Novruzi T. 1989. Threshold conditions for rill initiation on a vertisol, Gunnedah, N.S.W., Australia. Catena 16: 101-110.

Dou GR. 1999. Incipient motion of coarse and fine sediment. Chinese Journal of Sediment Research (6): 1-9.

Elliot WJ, Laflen JM. 1993. A process-based rill erosion model. Transactions of the ASAE 36(1): 65-72.

Engelund F, Fredsoe J. 1976. A sediment transport model for straight alluvial channels. Nordic Hydrology 7: 293-306.

Favis-Mortlock DT. 1998. A self-organising dynamic systems approach to the simulation of rill initiation and development on hillslopes. Computers and Geosciences 24(4): 353-372.

Foster GR, Meyer LD. 1972a. A closed-form soil erosion equation for upland areas. In Sedimentation: Symposium to Honor Professor HA, Einstein, Shen HW (ed.). Colorado State University: Fort Collins, CO; 12.1-12.19.

Foster GR, Meyer LD. 1972b. Transport of soil particles by shallow flow. Transactions of the American Society of Agricultural Engineers 15: 99-102.

Foster GR, Huggins LF, Meyer LD. 1984a. A laboratory study of rill hydraulics: I. Velocity relationships. Transactions of the ASAE 27(3) 790-796.

Foster GR, Huggins LF, Meyer LD. 1984b. A laboratory study of rill hydraulics: II. Shear stress relationships. Transactions of the ASAE 27(3): 797-804.

Foster GR, Lane LJ, Nearing MA. 1989. Erosion component. In USDA-Water Erosion Prediction Project, Hillslope Profile Model Documentation. NSERL Report No. 2, US Department of Agriculture, Agricultural Research Service, National Soil Erosion Research Laboratory, West Lafayette, IN; 10.1-10.12.

Gilley JE, Finckner SC, Nearing MA, Lane LJ. 1989. Hydraulics of overland flow. In Lane LJ, Nearing MA (eds). USDA-Water Erosion Prediction Project: Hillslope Model Documentation, NSERL Report 
No. 2, US Department of Agriculture, Agricultural Research Service, National Soil Erosion Research Laboratory, West Lafayette, IN, 9.1-9.4.

Gilley JE, Kottwitz ER, Simanton JR. 1990. Hydraulic characteristics of rills. Transactions of the ASAE 33: 1900-1906.

Govers G, Poesen JWA. 1988. Assessment of interrill and rill contribution to total soil loss from an upland field plot. Geomorphology 1(4): 343-345.

Hairsine PB, Rose CW. 1992. Modeling water erosion due to overland flow using physical principles: 2. Rill flow. Water Resources Research 28: $245-250$.

Horton RE. 1945. Erosional development of streams and their drainage basins; hydrophysical approach to quantitative morphology. Geological Society of America Bulletin 56: 275-370.

Huang CH, Bradford JM, Laflen JM. 1996. Evaluation of the detachmenttransport coupling concept in the WEPP rill erosion equation. Soil Science Society of America Journal 60: 734-739.

Lei AL, Tang KL. 1998. Dynamics condition of rill erosion on loess hillslope. Chinese Journal of Soil Erosion and Soil and Water Conservation 4(3): 39-43.

Lei T, Nearing MA, Haghighi K, Bralts VF. 1998. Rill erosion and morphological evolution: a simulation model. Water Resources Research 34: 3157-3168

Li JC, Liu QQ, Zhou JF. 2003. Environmental mechanics in China. Advances in Applied Mechanics. 39: 217-306.

Low HS. 1989. Effect of sediment density on bed-load transport. Journal of Hydraulic Engineering 115: 124-138.

Merten GH, Nearing MA, Borges ALO. 2001. Effect of sediment load on soil detachment and deposition in rills. Soil Science Society of America Journal 65: 861-868.

Merz W, Bryan RB. 1993. Critical conditions for rill initiation on sandy loam Bounisols: laboratory and field experiments in southern Ontario. Canada Geoderma 57: 357-385.

Nearing MA, Norton LD, Bulgakov DA, Larionov GA, West LT, Dontsova KM. 1997. Hydraulics and erosion in eroding rills. Water Resources Research 33: 865-876.

Poesen JWA, Vandaele K, van Wesemael B. 1998. Gully erosion: importance and model implications. In Modelling Soil Erosion by Water, Boardman J, Favis-Mortlock D (eds). Springer-Verlag: Berlin; 285-311.

Rauws G, Govers G. 1988. Hydraulic and soil mechanical aspects of rill generation on agricultural soil. Journal of Soil Science 39: 111-124.

Renard KG, Foster GA, Weesies DK, McCool DK, Yoder DC. 1997. Predicting soil erosion by water: a guide to conservation planning with the revised universal soil loss equation. In Agriculture Handbook No. 703. United States Department of Agriculture: Washington, DC.

Rice CT, Wilson BN. 1990. Analysis of dynamic variables of rill flow. ASAE paper 902011, ASAE, St Joseph, MI.

Shainberg I, Goldstein D, Levy GJ. 1996. Rill erosion dependence on soil water content, aging, and temperature. Soil Science Society of America Journal 60: 916-922.

Sirjacobs D, Shainberg I, Rapp I, Levy GJ. 2001. Flow interruption effects on intake rate and rill erosion in two soils. Soil Science Society of America Journal 65: 828-834.

Wischmeier WH, Smith DD. 1978. Predicting rainfall erosion losses. In US Department of Agriculture (USDA) Handbook No. 537, US Government Printing Office, Washington DC, USA.

Yalin MS. 1963. An expression for bed-load transportation. ASCE, Journal of the Hydraulics Division 89: 221-248.

Yang CT. 1973. Incipient motion and sediment transport. ASCE, Journal of the Hydraulics Division 99: 1679-1703.

Zhang KL. 1999. Hydrodynamic characteristics of rill flow on loess slopes. Chinese Journal of Sediment Research (1): 56-61.

Zhang KL, Akiyoshi Y, Zhang XQ. 1998. A laboratory study on rill erosion and sediment delivery on the slope. Chinese Journal: Geographical Research 17(2): 163-170.

Zheng FL, Kang SZ. 1998. Erosion and sediment yield in different zones of Loess slopes. Chinese Journal: Acta Geographica Sinica 53(5): $422-428$.

\section{APPENDIX A: NOTATION}

$a \quad$ parameter, $a=2.45 Y_{\mathrm{c}}^{0.5} / s^{0.4}$

$s^{*} \quad$ parameter, $s^{*}=\left(Y-Y_{\mathrm{c}}\right) / Y_{\mathrm{c}}$

$C \quad$ sediment concentration $\left(\mathrm{kg} \mathrm{m}^{-3}\right)$

$c_{\mathrm{f}} \quad$ conflux coefficient of overland flow concentrating into rills from interrill areas
$C_{*}$ sediment concentration of carrying capacity $\left(\mathrm{kg} \mathrm{m}^{-3}\right)$

diameter of sediment $(\mathrm{m})$

$d^{\prime} \quad$ characteristic diameter (m)

$D_{\mathrm{r}} \quad$ rill erosion rate $\left(\mathrm{kg} \mathrm{m}^{-2} \mathrm{~s}^{-1}\right)$

$D_{\text {rr }} \quad$ interrill spacing $(\mathrm{m})$

$d_{0} \quad$ referenced diameter $(\mathrm{m})$

$d_{25}$ grain diameter that $25 \%$ of the total particles by weight are finer $(\mathrm{m})$

$d_{50} \quad$ median grain size of sediment $(\mathrm{m})$

$d_{*} \quad$ referenced diameter $(\mathrm{m})$

$G$ parameter, Equation (9)

$g \quad$ acceleration due to gravity $\left(\mathrm{m} \mathrm{s}^{-2}\right)$

$G_{\text {down }}$ settling flux of sediment $\left(\mathrm{kg} \mathrm{m}^{-2} \mathrm{~s}^{-1}\right)$

$G_{\text {up }}$ entrainment flux of sediment from bed $\left(\mathrm{kg} \mathrm{m}^{-2}\right.$ $\left.\mathrm{s}^{-1}\right)$

$h \quad$ water depth (m)

$h_{0} \quad$ water depth parameter (m)

$K$ saturated conductivity of soil (or infiltration coefficient) $\left(\mathrm{m} \mathrm{s}^{-1}\right)$

$k$ non-dimensional parameter, $k=0 \cdot 128$

$L \quad$ length of slope (m)

$L_{\alpha} \quad$ parameter, $L_{\alpha}=1 / \alpha$

$n \quad$ Manning roughness coefficient

$p \quad$ wetted perimeter of rill $(\mathrm{m})$

$Q \quad$ discharge of rill flow $\left(\mathrm{m}^{3} \mathrm{~s}^{-1}\right)$

$q \quad$ unit discharge of overland flow $\left(\mathrm{m}^{2} \mathrm{~s}^{-1}\right)$

$q_{\mathrm{s}} \quad$ sediment transport rate per unit width $\left(\mathrm{kg} \mathrm{m}^{-1} \mathrm{~s}^{-1}\right)$

$R$ hydraulic radius (m)

$r \quad$ correlation coefficient

$S \quad$ soil suction $(\mathrm{m})$

$s \quad$ parameter, $s=\rho_{\mathrm{s}} / \rho$

$S_{0} \quad$ slope gradient, $S_{0}=\sin \theta$

$t$ coordinates of time (s)

$t_{0} \quad$ time parameter (s)

$T_{\mathrm{c}} \quad$ unit transport capacity of rill flow $\left(\mathrm{kg} \mathrm{m}^{-1} \mathrm{~s}^{-1}\right)$

$u \quad$ mean velocity of rill flow $\left(\mathrm{m} \mathrm{s}^{-1}\right)$

$W \quad$ width of slope (m)

$x \quad$ coordinate along the slope $(\mathrm{m})$

$Y \quad$ dimensionless shear stress, $Y=\tau /\left[\left(\rho_{\mathrm{s}}-\rho\right) g d\right]$

$Y_{\mathrm{c}} \quad$ dimensionless critical shear stress, $Y_{\mathrm{c}}=\tau_{\mathrm{c}} /\left[\left(\rho_{\mathrm{s}}-\right.\right.$ $\rho) g d]$ coefficient $\left(\mathrm{m}^{-1}\right)$

$\delta \quad$ thickness parameter of the water film (m)

$\varepsilon_{0} \quad$ parameter of the adhesion force $\left(\mathrm{m}^{3} \mathrm{~s}^{-2}\right)$

$\gamma_{0} \quad$ dry specific weight of soil $\left(\mathrm{N} \mathrm{m}^{-3}\right)$

$\gamma_{0 *} \quad$ stable dry specific weight of soil $\left(\mathrm{N} \mathrm{m}^{-3}\right)$

$\gamma_{\mathrm{s}} \quad$ specific weight of the sediment $\left(\mathrm{N} \mathrm{m}^{-3}\right)$

$\lambda$ probability of settling of per sediment particle during time $t_{0}$

slope angle $\left(^{\circ}\right)$

$\theta_{\mathrm{i}} \quad$ initial volumetric water content $\left(\mathrm{m}^{3} \mathrm{~m}^{-3}\right)$

$q_{\mathrm{s}} \quad$ saturated volumetric water content $\left(\mathrm{m}^{3} \mathrm{~m}^{-3}\right)$

$\rho \quad$ density of fluid $\left(\mathrm{kg} \mathrm{m}^{-3}\right)$

$\rho_{\mathrm{s}} \quad$ density of sediment $\left(\mathrm{kg} \mathrm{m}^{-3}\right)$

$\tau \quad$ flow shear stress $(\mathrm{Pa})$

critical shear stress $(\mathrm{Pa})$

$\omega \quad$ settling velocity of sediment particles $\left(\mathrm{m} \mathrm{s}^{-1}\right)$ 